\title{
Structure, Conduct and Performance of Indian Banking Sector
}

\section{Deepti Sahoo $^{1}$ and Pulak Mishra ${ }^{2}$}

\begin{abstract}
In the context of initiation of economic reforms in general and changes in policies and regulations of the banking sector in particular, the present paper attempts to examine the structure-conduct-performance relationships in Indian banking sector. It is observed that there have been changes in the market structure of Indian banking sector, conducts of the banks and their performance in the post-reform era, especially during the last decade, though the changes have not been significant in every aspect. Using a panel dataset of 59 banks operating in India during 1999-2000 to 2008-2009 and applying the two-stage least squares (2SLS) method of estimation, the paper finds that there exist strong inter-linkages amongst structure of the market, banks' conduct and their financial performance. While market share of a bank depends directly on its market size, asset base, selling efforts, and past financial performance, its selling efforts vary directly with market share, asset base, and past financial performance. On the other hand, returns on assets of a bank vary directly with its market share, but inversely with its asset base and selling efforts. The regression results essentially suggest for multidirectional and dynamic SCP relationships in Indian banking sector. It is also found that the nature of ownership has significant influence on market share, selling efforts and financial performance of the banks. As compared to the nationalised banks, market share of the private banks (both domestic and foreign) is found to be lower. But private banks make greater selling efforts and have better financial performance vis-àvis their public sector counterparts.
\end{abstract}

Key words: Banking sector, market structure, conduct, performance, policy, India

JEL Classification: C33, G18, G21, L190

\section{Introduction}

The Indian banking sector has taken a new dimension with initiation of economic reforms in 1991 in general, and changes in sector specific policies and regulations since the mid-1990s in particular. The basic objectives of these measures were to make Indian banking sector internationally competitive, especially in respect of capital adequacy and other prudential norms. Accordingly, emphasis has been given on improving productivity, efficiency, technology, and profitability of the banks. Given that achieving greater efficiency and competitiveness requires enhanced market competition, a number of deregulatory policy measures have been introduced. Introduction of these

\footnotetext{
${ }^{1}$ Faculty in Economics, Department of Humanities and Social Sciences, RGUKT, IIIT Nuzvid, India, Email: sahood9@gmail.com

${ }^{2}$ Associate Professor in Economics, Department of Humanities and Social Sciences, Indian Institute of Technology Kharagpur, India, Email: pmishra@hss.iitkgp.ernet.in
} 
deregulatory polices is largely based on the assumption that efficiency of banks increases in a competitive environment.

However, instead of drastic privatization of the existing public sector banks, Indian government has chosen a gradual approach towards their restructuring to enhance competitiveness. What is more important, perhaps, is that with deregulation leading to competitive business environment in the sector, the banks have also applied a variety of strategies to cope with the emerging market conditions. The major strategies applied by the banks under the new business conditions include differentiating products/services and creating strategic entry barriers through advertising, widening customer base through promotional activities, diversification of product/service portfolio to reduce risks of operation, mergers and acquisitions to consolidate business and enhance efficiency, and floating joint ventures with foreign banks to bring in better management and enhance capital base.

Thus, reforms in Indian banking sector have resulted in two opposite forces. While the policy and regulatory changes are expected to bring in greater competition in the market and, thereby, to enhance efficiency of the banks, the strategic responses of the banks are likely to limit market competition. This raises some important issues. How have the policies of the government and strategic responses of the banks affected structure of the market in Indian banking sector? What are the factors that determine strategies of the banks? How have the domestic players performed vis-à-vis their foreign counterparts under the new business conditions? What regulatory role should the Reserve Bank of India (RBI) play to ensure greater market competition and better efficiency of the banks?

The rationale for raising these issues lies in the structure-conduct-performance (SCP) relationships, propounded initially by Mason (1939) and modified subsequently by Bain (1959). The traditional SCP framework suggests that the possibility of collusive behaviour increases when the market is concentrated in the hands of a few firms, and the higher the market concentration, the larger will be the profitability of the firms. In other words, there is a positive correlation between market concentration and performance of firms. Many studies have attempted to test validity of the basic proposition of the traditional SCP paradigm that the market concentration lowers the cost of collusion between firms, and results in higher than normal profits. There are a numerous studies (e.g. Weiss, 1974) that have found a positive relationship between market structure and performance of firms.

The SCP relationships in banking sector are well explored in the literature. The existing studies in general have attempted to test the hypothesis that market concentration significantly influences performance of banks. A large number of these studies find evidence in support of the hypothesis that market concentration enhances banks' performance (Edward, 1964; Phillips, 1967; Brucker, 1970; Vernon, 1971; Gilbert, 1984; Podenda, 1986; Evanoff and Fortier, 1988; Molyneux and Thornton, 1992; Lloyad-Williams et al., 1994; Molyneux and Forbes, 1995; Katib, 2004). These studies in general show that market concentration in the sector affects the price which consumers pay for banking services and this in turn influences their financial performance. However, contrary to this observation, there are also studies (e.g., Smirlock, 1985; Miller and VanHoose, 1993) that either do not support or reject the hypothesis that market concentration has a positive impact on performance of banks. 
Similarly, in Indian context, the studies by Bhattacharya and Das (2003), Sathye and Sathye (2004), and Varma and Sainir (2010) do not find evidence in support of this traditional SCP hypothesis.

The inconsistencies and contradictions in the SCP relationships in the literature are generally contributed to the methodology and data, and the assumptions relating to measures of market structure (Osborne and Wendel, 1983; Gilbert, 1984). Further, interpreting higher profits in concentrated markets as evidence of market power is also problematic as market concentration may not necessarily be a reflection of collusive behaviour of the banks, rather a consequence of their superior efficiency (Demsetz, 1974; Smirlock, 1985; and Bresnahan, 1989). There are studies in Indian context as well (e.g., Sathye and Sathye, 2004; Varma and Sainir, 2010) which have found efficiency as an important determinant of banks' performance. This means that, in addition to use of appropriate methodology and consistent data, a proper understanding of the SCP relationships requires simultaneous consideration of both market power and efficiency. But, this aspect has remained largely unexplored in the existing studies.

Second, although the literature on competition is based on two predominant views, viz., the static and the dynamic view, with innovations resulting in new products and new markets, disequilibrium in the existing markets is very likely in the long run, particularly when entry and exit are free (Mueller, 1990). This makes the players engaged in dynamic competitive process through various business strategies to gain advantage over the rivals (Kirzner, 1973; Shackle, 1971). Hence, competition should be viewed as a dynamic process of rivalry (Vickers, 1995). But, the existing studies have largely focused on static analysis, and thereby have failed to incorporate variations in bank and service specific competencies, growth of banks and the sector, and entry into and exit from the sector. This is very important as the dynamics of competition in Indian banking sector are expected to be influenced by structure of the market, conducts of the banks and their performance (Bhanumurthy and Dev, 2008).

Hence, the SCP relationships in the context of banking sector should be explored in a multidirectional and dynamic framework. The present paper is an attempt in this direction. Such an effort is very important as there is no consensus in the literature about the possible impact of deregulation on efficiency and financial performance of the banks. While the proponents of the beneficial role of financial services in a free economy (Cho, 1986) tend to undermine the scope of unruly behaviour, there is also every possibility of over speculation, financial crisis and misallocation of savings and investment to the detriment of growth and stability (Singh, 1993; Grabel 1995). Experiences of India and other developing countries largely support the second view (Ram Mohan, 2001). The rest of the paper is organized in the following way: The second section discusses the state of market structure, conduct of banks and their performance in the last decade. The multidirectional and dynamic SCP relationships in the sector are specified in the third section. The fourth section of the paper describes the estimation techniques applied and sources of data used, whereas the fifth presents and discusses the empirical findings. The sixth section sums up the major findings and concludes the paper. 


\section{SCP in Indian Banking Sector: An Overview}

As mentioned above, the traditional SCP framework postulates a unidirectional relationship between market structure, conduct and performance with structure of the market (concentration, conditions on entry, etc.) influencing performance of the firms (profits, growth, etc.) via their conducts (price and non-price behaviour). It is observed that higher market concentration results in higher prices and hence in higher financial returns. A number of studies (e.g., Berger and Hannan, 1989; Hannan, 1992; Neumark and Sharpe, 1992; Okeahalam, 1998; Prager and Hannan, 1998) support this traditional SCP relationship.

However, there are a number of studies that cast doubt on the unidirectional SCP relationship. According to Demsetz (1973) and Berger (1995), when larger market shares are results of better efficiency and lower costs, adverse impact on welfare does not arise. On the other hand, when higher market concentration raises prices, quantity demanded declines and hence profits may not necessarily increase (Mullineux and Sinclair, 2000). ${ }^{3}$ Successive developments in the industrial organization literature have addressed these aspects in a multidirectional structure-conduct-performance-policy framework (e.g., Scherer and Ross, 1990). In the modified SCP framework, interdependencies amongst market structure, conducts of banks and their performance make the variables endogenous in nature (Scherer and Ross, 1990; Neuberger, 1997). Inclusion of public policy and feedback effects make the framework interlinked further.

Further, given that the banks are special players in the market for information, market conditions are very important for determination of their relative position in the market, strategic behaviour and performance. Therefore, incorporation of different aspects of incomplete information is necessary for better understanding of the SCP relationships in the banking sector (Swank 1996, Thakor 1995, Neuberger 1997). Integration of such market imperfections arising from market uncertainties, asymmetric information, transaction costs and information costs into the basic market conditions, and functioning of the market seem to have a significant impact on structure of the banking sector, strategic behaviour of the banks and their performance. The modified SCP framework in the context of banking sector, as suggested by Neuberger (1997), is shown in Figure 1. Here, the basic market conditions include risks, attitudes towards risks and principalagent-relationships. These basic conditions affect market structure, conduct, performance, and public policies against market failures. Given this backdrop, what follows next is an attempt towards empirical understanding of the SCP relationships in Indian banking sector. ${ }^{4}$

\footnotetext{
${ }^{3}$ The findings of Shaffer (1989) also do not support the basic proposition of the traditional SCP framework.

${ }^{4}$ Due to non-availability of necessary data, the present paper fails to capture the impact information asymmetry on basic conditions of the market. However, here, we capture the importance of transaction costs in terms of cost and operational efficiency of the banks.
} 
Figure 1: SCP Framework for Banking Sector

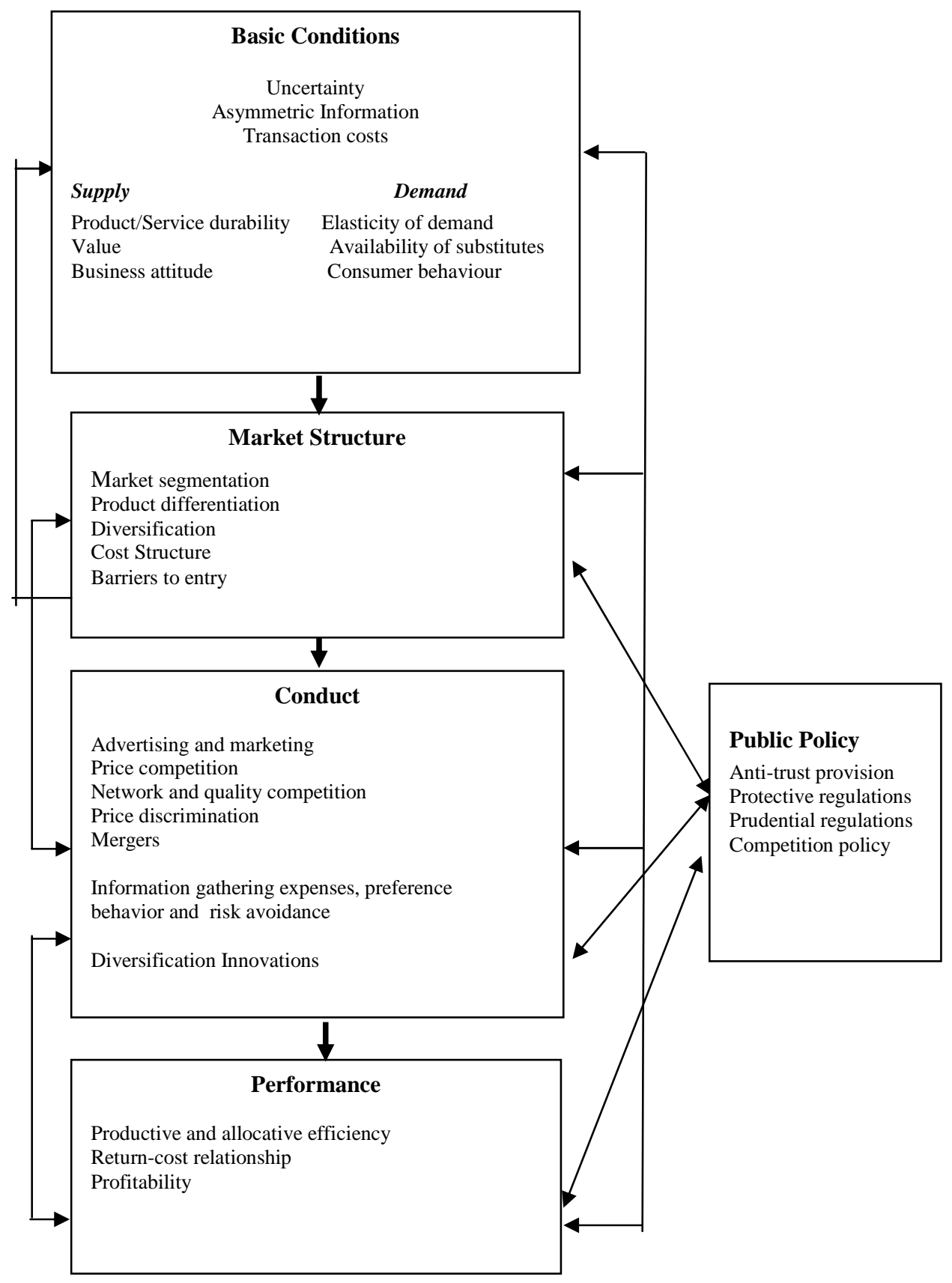

Source: Neuberger (1994) 


\section{Structure of the Market}

Generally, the structure of a market is examined in terms of the degree of sellers' concentration as it is an important feature of the extent of imperfect competition in the market. The industrial organization literature suggests several measures of market concentration to infer about the structure of a market, such as market shares of the firms, n-firm concentration ratio, Herfindahl-Hirschman Index (HHI), price-cost margin, profitability, etc. ${ }^{5}$ In the present paper, four indices have been used namely, market shares of the banks, n-bank concentration ratio, the HHI, and the entropy index to measure the extent of market concentration in Indian banking sector. While market share will signal position of an individual bank in the market, the 3-bank concentration ratio, the HHI, and the entropy index will measure the degree of concentration in the market as a whole. ${ }^{6}$ In addition, the present paper also examines size of a bank in terms of its gross fixed assets in order to shed some light on the scale of operations, and the demand for its products/services in terms of income to understand the basic market conditions.

The trends in composition of the sector in terms of the number of banks in the Prowess database of the Centre for Monitoring Indian Economy (CMIE) are presented in Table 1. It is observed that private banks, especially the foreign ones, have a very strong presence in Indian banking sector and in terms of their number, nationalized banks account for only around one-fourth of the sector. While the number of nationalized bank has declined only marginally after 2006, that of other types of banks have fluctuated over the years. Table 2 shows the average market size of the banks and their average asset base. ${ }^{7}$ Both the average market size and asset base of the banks have increased during 2000-01 to 2009-2010. However, there have not been considerable variations in these measures implying that the market size or the asset base has been consistent across the banks.

\footnotetext{
${ }^{5}$ In Indian context also, the existing studies have largely used these measures to examine the state of market concentration. For example, while Kambhampati (1996) has assessed structure of the market in Indian industry sector on the basis of n-firm concentration ratio, Ramaswamy (2006), Mishra and Behera (2007), and Mishra (2008) have used the HHI for the same. On the other hand, Basant and Morris (2000), and Mishra (2005) have used n-firm concentration ratio and price-cost margin along with the HHI to substantiate the findings. Contrary to this, Pushpangadan and Shanta (2008) have examined the dynamics of market competition in terms of persistence of the profit rates.

${ }^{6}$ In this context, it should be mentioned that the $\mathrm{n}$-firm concentration ratio has a number of limitations. The magnitude of the ratio is largely influenced by the choice of $\mathrm{n}$ and also by how a market is defined, and the measure does not take into account the entire number and size distribution of the firms. Despite these limitations, the present study uses this measure as it is the most commonly used index of market concentration because of the ease of computation and interpretation of the results. However, the HHI satisfies all the desirable properties by combining both the number and size distribution of firms in the industry and is considered as a better measure of market concentration. Further, by squaring market shares, the HHI weights more heavily the values for large firms than for small ones. A simultaneous consideration of the two indices helps in substantiating the findings.

${ }^{7}$ In the present study, the natural logarithm of gross fixed assets of a bank is used as a measure of its size (asset base), whereas the natural logarithm of income is considered as a proxy for its market size.
} 
The average market share of the banks has been very low during the period under consideration (Table 3). ${ }^{8}$ However, the market share has differed considerably across the banks though the extent of variations has declined over the years. The other indices, viz., the 3-firm concentration ratio, the HHI, and the entropy index show that the extent of market concentration in the sector has been reasonably low. ${ }^{9}$ These measures also show decrease in market concentration during this period, though the decline has not been significant.

\section{Conduct of the Banks}

Under imperfect competition, financial performance of a bank depends to a large extent on its selling effort that includes advertising and marketing of products/services, and development of service networks. Advertising influences financial performance of a bank by differentiating its products/services from that of the rivals, creating entry barriers, and enhancing image. Pursuing the consumers in favour of these differentiated products/services makes the demand inelastic over the alternatives and hence results in increased control of the bank over the market. Advertising also creates barriers to entry of new banks as well as that to the upward mobility of the smaller banks. Advertising by the entrants can help them to become recognized in the market, but intensive counter advertising by the incumbents drowns out entrants' images and, thereby, lessens the volume of market they can capture. All these limit competition in the market and thereby improve financial performance of the banks. ${ }^{10}$

On the other hand, expenditure by the banks towards building up marketing and distribution related complementary assets improves financial performance in two ways. First, such efforts raise competitiveness of the banks by developing marketing and service networks, which, in turn, facilitates appropriateness of products/services and enhances efficiency. Second, such assets increase bargaining power of the banks in equity linked foreign collaborations as they have wider services networks as compared to the foreign banks.

In the present paper, strategic behaviour of the banks is examined in terms of their selling efforts. Here, selling intensity (i.e., the ratio of total selling expenses to income) of a bank is used as a measure of its selling efforts. The selling efforts refer to expenses by the bank towards advertising, promotion of services, and developing service networks. Table 4 presents the selling efforts of the banks operating in India. It is observed that the average selling intensity has been very low but has recorded increasing trends over the years. This means that the banks operating in India have increasingly used selling strategies to strengthen their position in the market. However, selling efforts have varied considerably across the banks.

\footnotetext{
${ }^{8}$ Here, market share of a bank is measured in terms of the ratio of its income to total income of all the banks in the sector.

${ }^{9}$ The HHI is measured as the sum of the squares of market shares of all the banks existing in the sector. On the other hand, the entropy index measures market concentration in terms of weighted average of market share with logarithm of reciprocal of market share itself being the weight.

${ }^{10}$ However, advertising can also facilitate entry of new banks by helping them in making their product/services known to the consumers quickly so that the concentration increasing effect can be dissipated or even reversed.
} 


\section{Performance of the Banks}

There are two broad strands of examining the financial performance of an enterprise, viz., the stock market approach, and the profitability. The stock market approach applies valuations in the stock market to determine the financial performance of an enterprise. This approach is based on the assumption that the stock market is efficient and assesses performance in terms of changes in share prices controlling for movements in the market in general and the systematic risks in particular. However, the stock price approach may suffer from the problem of undervaluation or overvaluation if the share prices incorporate random valuation errors. When it is so, the changes in share prices may largely be due to market correction. In this perspective, the profitability approach is considered as much simpler measure of financial performance (Rhoades, 1985; Evanoff and Fortier, 1988). ${ }^{11}$

The present paper uses the profitability approach to assess financial performance of the banks during the post-reform period. Three alternative indices of profitability, viz., the ratio of profit before interest and taxes (PBIT) to total income, the ratio of PBIT to gross fixed assets, and the ratio of PBIT to capital employed have been computed to substantiate the findings. While the ratio of PBIT to total income is termed as profitability, the ratio of PBIT to gross fixed assets is referred as returns on assets. On the other hand, the ratio of PBIT to capital employed is termed as the returns on capital employed. In addition, the present paper also assesses operating efficiency of the banks in terms of their cost efficiency and the current ratio.

It is observed that financial performances of the banks have fluctuated during 2000-01 to 2009-10 and the fluctuations are high in the case of ROCE (Table 5). Further, the financial performance has varied across the banks and the difference in quite high in case of ROCE. The same can be said in respect of the current ratio (i.e., the ratio of current assets to current liabilities) as well (Table 6). As regards the costs efficiency, the banks have shown signs of improvement over the years and the difference across the banks has not been very high except that in 2006-07. However, total costs efficiency has varied considerably across the banks (Table 6). ${ }^{12}$

The above discussions, therefore, show some interesting dynamics relating to market structure of Indian banking sector, strategic behaviour of the banks and their financial performance. While dominance of the private banks has continued in terms of their number vis-à-vis the public sector banks, average size (asset base) of a bank and its market size have shown increasing tendency during 2000-01 to 2009-10. However, despite introduction of a number of liberal policy measures, extent of market concentration in the sector shows only marginal decline. Under the new business conditions the banks have increasingly relied on non-price competitive strategies like selling efforts, but, financial performance or efficiency does not show much

\footnotetext{
${ }^{11}$ However, the profitability approach itself has problems as companies can use creative accounting techniques especially in respect of sales, assets, and profits and, therefore, the published accounts may not be a true or fair reflection of their financial performance (Griffiths, 1986).

${ }^{12}$ In the present study, cost intensity of a bank, i.e. the ratio of its total expenditure to income is used as a measure of cost efficiency. It is assumed that higher cost intensity stands for lesser costs efficiency of the bank.
} 
improvement. This raises a few important issues. Why do the policy reforms fail to enhance the extent of competition in Indian banking sector? How do market structure and strategies affect business performance of the banks? Does control over the market or business strategy or performance of a bank depend on its nature of ownership? Answering these questions requires identifying the determinants of market structure of the banking sector, business strategies of banks and their financial performance in a multidirectional and dynamic SCP framework. The next section of the paper is an attempt in this direction.

\section{SCP Relationships in Indian Banking Sector: Model Specification}

The existing literature on industrial organization (e.g., Bain, 1951; Gupta, 1983; Schmalensee, 1989; Baker and Woodward, 1998) proposes various econometric techniques to empirically analyze the SCP relationships. However, in the present paper, following Khambampati (1996), simultaneous equation approach is applied. This approach contains three different models assuming that each of structure $(\mathrm{S})$, conduct $(\mathrm{C})$ and performance $(\mathrm{P})$ is a function of the other two aspects ${ }^{13}$, i.e.,

$$
S=f_{1}(C, P), C=f_{2}(S, P), P=f_{3}(S, C)
$$

In the present paper, market share (SHRARE) is taken as a proxy for market structure, selling intensity (SELL) for conduct, and returns on assets (ROA) for financial performance (PER). While market share reflects both efficiency and market power (Smirlock, 1985; Evanoff and Fortier, 1988; Frame and Kamerschen, 1997), selling intensity can capture product differentiation with price competition (Hannan, 1991b; Ciappori et al., 1995). On the other hand, return on assets is a much simpler and more widely used measure of financial performance of a bank (Rhoades, 1985; Evanoff and Fortier, 1988). However, market share of banks may be influenced by other structural aspects of the market like their market size (MSZ) and asset base (BSZ), whereas, returns on assets can be affected by their cost inefficiency (COST). Similarly, selling efforts by the banks can be influenced by other business strategies as well. Hence, the system of equations mentioned above can be rewritten as:

$$
\text { SHARE }=\phi_{1}\left(S^{\prime}, C, P\right), S E L L=\phi\left(S, C^{\prime}, P\right), R O A=\phi\left(S, C, P^{\prime}\right)
$$

Here, $S^{\prime}$ 'stands for set of variables relating to market structure other than market share of the banks, C' for conduct other than their selling efforts, and $\mathrm{P}^{\prime}$ for their performance other than returns on assets. However, the functional relationships may not necessarily be instantaneous in nature Kambhampati (1996). Instead, lagged relationships amongst many of the constituent variables are very likely. For example, lagged conduct and

\footnotetext{
${ }^{13}$ The ideal way of modeling structure-conduct-performance-policy relationships is to estimate a system of at least four equations, one for each market structure, business strategies, performance, and policies. But, due to lack of adequate information on policy changes, in the present paper, the relationships are envisaged with three equations. Further, the impact of any policy change is unlikely to be significantly different across the banks. There is a number of studies (e.g., Strickland and Weiss, 1976; Martin, 1979a and 1979b; Delorme et. al., 2002) that analyze the SCP relationships by using three equations.
} 
lagged performance can affect market concentration (Kambhampati, 1996). Similarly, conduct of a bank is likely to be influenced by lagged performance. Accordingly, appropriate lag structure is incorporated in the models. The lag structure can also control the dynamics of the envisaged relationships in addition to reducing the problem of endogeneity.

\section{Determinants of Market Structure}

We assume that market share of a bank (SHAREit) is a function of its current bank size (BSZit), lagged market size (MSZi,t-1), lagged selling intensity (SELLi,t-1), lagged returns on assets (ROAi,t-1), and nature of ownership, i.e.,

$S_{H A R E_{i t}}=f_{1}\left(B S Z_{i t}, M S Z_{i, t-1}, S E L L_{i, t-1}, R O A_{i, t-1}, D_{1}, D_{2}\right)$

Here, MSZi,t-1 and BSZit are proxy for structural aspects of the market other than market share, SELLi,t-1 for strategy, ROAi,t-1 for performance, and D1 and D2 for nature of ownership of the banks. All banks are divided into three categories, viz., public sector banks, private domestic banks, and private foreign banks. The public sector banks are considered to be the base category. As such, D1 = 1 for private domestic banks and $\mathrm{D} 1=0$ otherwise, whereas $\mathrm{D} 2=1$ for private foreign banks and D2 $=0$ otherwise. Assuming the functional relationship to be linear, (1) can be rewritten as,

$$
\begin{aligned}
& \operatorname{SHARE}_{i t}=\alpha+\beta_{1} \mathrm{BSZ}_{i t}+\beta_{2} M S Z_{i, t-1}+\beta_{3} S E L L_{i, t-1}+\beta_{4} R O A_{i, t-1}+\beta_{5} D_{1}+ \\
& +\beta_{6} D_{2}+u_{i t}
\end{aligned}
$$

\section{Possible Impact of the Independent Variables}

Current Bank Size (BSZit): Size of a bank, measured in terms of its asset base, can be seen as a proxy for the scale of operation. It is expected that larger banks operate at higher scale. This helps the banks to reap the benefits of economies of scale, and thereby to have greater share in the market. Hence, one may expect direct influence of asset base on market share of a bank.

Lagged Market Size (MSZi,t-1): In the present paper, market size is used to proxy demand for services of a bank, i.e., to indicate its absolute position in the sector. Given the size of the sector, the banks with greater demand for their services are expected to have larger share in the market. In other words, market share of a bank is likely to vary directly with its market size. However, when market size of other banks also changes, the relative position of a particular bank in the market may not necessarily alter.

Lagged Selling Intensity (SELLi,t-1): On the one hand, a bank disseminates information on its services as well as creates image advantage and barriers to entry through advertising. On the other hand, promotional efforts and widening of service networks help the banks in creating necessary complementary assets. All these give the bank an opportunity to raise its market share. Hence, market share of a bank is expected to vary directly with its selling efforts.

Lagged Return on Assets (ROAi,t-1): In general, better financial performance raises the ability and willingness of a bank to grow, and thereby can result in its higher market 
share. On the other hand, in the absence of entry barriers, better financial performance of the existing banks can encourage entry into the sector resulting in lower market share 14. Hence, the nature of impact of financial performance of a bank on its market share depends on the relative strength of these diverse forces.

Nature of Ownership (D1 and D2): As private banks are relatively new players in the sector and generally operate in the urban areas, they have lesser penetration in the market. Hence, the private banks are likely to have lesser market share vis-à-vis the public sector banks. In others words, one can expect the coefficient of D1 and D2 to be negative.

\section{Determinants of Conduct}

It is assumed that selling efforts of a bank (SELLit) is a function of its lagged market share (SHAREi,t-1), current asset base (BSZit), lagged financial performance (ROAi,t1), and the nature of their ownership (D1 and D2), i.e.,

$S E L L_{i t}=f_{2}\left(S H A R E_{i, t-1}, B S Z_{i t}, R O A_{i, t-1}, D_{1}, D_{2}\right)$

Here, SHAREit, and BSZit control for structural aspects of the market, ROAi,t-1, for banks' performance, and D1 and D2 for their nature of ownership. Assuming the functional relationship to be linear, (3) can be rewritten as,

$$
S E L L_{i t}=\alpha+\beta_{1} S H A R E_{i, t-1}+\beta_{2} B S Z_{i t}+\beta_{3} R O A_{i, t-1}+\beta_{4} D_{1}+\beta_{5} D_{2}+v_{i t}
$$

\section{Possible Impact of the Independent Variables}

Lagged Market Share (SHAREit): A higher market share of a bank may increase the threats of new entry as well as strategic competition from existing rivals. When it is so, the bank needs to protect its market share through selling related efforts. Hence, the banks with higher market share are expected to have greater selling intensity.

Current Bank Size (BSZit): A larger bank has greater ability to spend on selling. A larger bank may also become complacent and, hence, may have lesser willingness to make selling related efforts. The nature of impact of bank size on selling intensity, therefore, depends on how these diverse forces dominate each other.

Lagged Return on Assets (ROAi,t-1): On the one hand, better financial performance can induce a bank to spend more on selling to create entry barriers or image advantage in the market. On the other hand, better financial performance can make the bank complacent and, hence, may restrict its selling related efforts. The nature of impact of financial performance on selling intensity, therefore, depends on the relative strength of these two opposite forces.

Nature of Ownership (D1 and D2): The private banks are considered to be more strategy oriented to raise their dominance over the market and, thereby, to enhance financial

\footnotetext{
${ }^{14}$ However, on many occasions, higher profitability of the incumbents can discourage entry of new banks. This is so particularly when higher profitability is a result of greater market power or larger scale of operation and the potential entrants do not have the capability to counter such dominance.
} 
performance. Hence, the private banks are likely to make greater selling related efforts vis-à-vis the public sector banks. In other words, one may expect the coefficients of D1 and $\mathrm{D} 2$ to be positive.

\section{Determinants of Performance}

It is assumed that the returns on assets of a bank (ROAit) depend on its current market share (SHAREit), current bank size (BSZit), lagged selling intensity (SELLit), current cost intensity (COSTit), and the nature of their ownership (D1 and D2), i.e.,

$$
R O A_{i t}=f_{3}\left(S H A R E_{i t}, B S Z_{i t}, S E L L_{i t-1}, C O S T_{i t}, D_{1}, D_{2}\right)
$$

Here, SHAREit, and BSZit control for structural aspects of the market, SELLit for conduct of the banks, COSTit, for their performance other than returns on assets. Assuming the functional relationship to be linear, (5) can be rewritten as

$$
\begin{aligned}
& R O A_{i t}=\alpha+\beta_{1} S H A R E_{i t}+\beta_{2} B S Z_{i t}+\beta_{3} S E L L_{i t-1}+\beta_{4} \operatorname{COST}_{i t}+\beta_{5} D_{1}+ \\
& +\beta_{6} D_{2}+\varepsilon_{i t}
\end{aligned}
$$

Possible Impact of the Independent Variables

Current Market Share (SHAREit): It is commonly perceived that higher market share enables a bank to enhance financial performance through greater efficiency and/or higher market power. However, when a bank strengthens its position in the market through various incentives to the customers, financial performance may not necessarily improve, especially in the short-run. The nature of impact of market share on financial performance of a bank, therefore, depends on the relative strengths of these diverse forces.

Current Bank Size (BSZit): A larger bank can operate at a higher scale and, therefore, can reap the benefits of scale economies. This helps the bank enhance its financial performance. However, if larger size of the bank results in X-inefficiency, its financial performance may not necessarily improve. Hence, the nature of impact of asset base of a bank on its financial performance depends on how these diverse forces dominate each other.

Lagged Selling Intensity (SELLi,t-1): Product differentiation and image advantage through advertising and creation of marketing and distribution related complementary assets are expected to enhance profitability of a bank. In other words, higher selling intensity of a bank is likely to enhance its financial performance.

Current Cost Intensity (COSTit): In general, cost intensity of a bank is likely to have a negative impact on its financial performance. The banks with higher cost intensity are expected to have lower returns on assets, particularly if it fails to cover the additional costs through greater services charges.

Nature of Ownership (D1 and D2): It is generally perceived that private banks are more efficient, and hence are likely to have better financial performance vis-à-vis the public sector banks. However, since private banks are relatively new in the sector, they operate at a smaller scale, which results in lower returns on assets as compared to the public 
sector banks. The impact of nature of banks on their financial performance, therefore, depends on how these diverse forces dominate each other.

\section{Estimation Techniques and Data}

The equations specified above are estimated with a pooled dataset of 59 banks operating in India over the period from 2000-01 to 2008-09. The sample includes 27 out of 28 public sector banks, 18 out of 22 foreign banks and 14 out of 16 private sector banks. Hence, a total of 59 banks are included in the sample. Cooperative banks and a few other banks are excluded due to non-availability of continuous data and on the basis of their peculiar operational system, too.

When there is no simultaneity bias, the method of ordinary least squares (OLS) results in consistent and efficient estimators. On the other hand, if there is simultaneity problem in the envisaged relationships, the OLS estimators are biased and inconsistent. The three equations specified above contain independent variables that are endogenous in nature. Therefore, the system cannot be estimated consistently by applying the OLS method of estimation. This is so because one of the crucial assumptions of the OLS method is that the explanatory variables are either non-stochastic or, even if stochastic, they are distributed independently of stochastic disturbance term. When neither of these conditions is satisfied, the OLS estimators become biased and inconsistent. This means that even if the sample size increases indefinitely, the estimates do not converge with their true values (Gujarati and Sangeetha, 2007).

Since in simultaneous equation models the endogenous variable in one equation appears as an explanatory variable in another equation of the system, this endogenous explanatory variable becomes stochastic and is usually correlated with the random disturbance term making the OLS estimators inconsistent (Gujarati and Sangeetha, 2007). Hence, in the present paper, the method of two-stage least square (2SLS) is applied in order to deal with the simultaneity problem. In the presence of simultaneity bias, the methods of two stage least squares (2SLS) and instrumental variables give estimators that are consistent and efficient.

In the present paper, the endogenous variables include current market share, current selling intensity, current returns on assets, current market size, current bank size, and current costs intensity. On the other hand, the lagged market size, lagged market share, lagged bank size, lagged selling intensity, lagged profitability, and nature of ownership are treated as the exogenous variables. ${ }^{15}$ In the first stage, the endogenous explanatory variables are regressed on all the exogenous variables included in the system. In the second stage, the predicted values of the endogenous explanatory variables from the first stage regression are used as their instruments for estimating the three structural equations. The lagged structure of the equations is also expected to control endogeneity problem of the independent variables. Further, all the variables included in the above models are converted into their natural logarithms. This has two advantages. First, the logarithmic transformation converts the individual slope coefficients into respective elasticity. This helps in determining the relative importance of the independent variables,

${ }^{15}$ In addition, the present paper also uses natural logarithm of the current ratio as additional instrumental variable. 
and thereby makes their effects comparable. Second, such an approach also reduces the scale of measurement of the variables and hence the problem of heteroscedasticity.

Further, since the present paper uses a pooled dataset of 59 banks over a period of 7 years, the time-series component is less as compared to the cross sectional units. This reduces the possibility of existence of unit roots. Despite that, the Levin-Lin-Chu (2002) panel data unit root test is carried out to examine if the dataset used in regression analysis suffers from the problem of non-stationarity. The panel data unit root test emerges from the time-series unit root tests. However, unlike the time-series unit root tests, the asymptotic behaviour of both the time-series dimension $\mathrm{T}$ and the crosssectional dimension $\mathrm{N}$ are taken into consideration in the panel unit root tests. The asymptotic behaviour of the estimators depends on the way in which $\mathrm{N}$ and $\mathrm{T}$ converge to infinity. The Levin-Lin-Chu Test (2002) panel unit root test is used to test the null hypothesis that all the panels contain unit root against the alternative hypothesis that each time series is stationary. If the null hypothesis is rejected for a variable, it implies that the concerned variable does not suffer from non-stationarity problem.

The present paper uses secondary data and the necessary data are collected from the Prowess database of the Centre for Monitoring Indian Economy (CMIE), Mumbai. The prowess database uses the initial sample from the database of the Reserve Bank of India (RBI) and then augments the data. There is a number of advantages connected with using this database since 1989-90. First, the Prowess database contains time-series information relating to the finances of the banks and the ratios based on them at bank level. The database is updated every day with regular intra-day and end-of-day updates. Second, Prowess is a normalized database. During the course of normalization, the data that come from heterogeneous sources are transformed into a standardized format to enable meaningful comparisons over time and across the banks. Such normalization is a necessary precondition in making the data comparable. Third, a merger is the most ambiguous observation of a bank as it ceases to exist as a separate legal entity following the integration. In such cases, the Prowess database retains all the information available regarding the bank till it was merged.

Necessary adjustments are made to make the dataset consistent. A three-year moving average is taken for each of the variables to control for the measurement errors and the process of adjustment. Accordingly, the variables are measured as simple average of the values of the previous three years with the year under reference being the starting year. Such approach of moving average with a lag of two years is expected to reduce the potential simultaneity bias further in the envisaged relationships.

\section{Results and Discussions}

Table 7 shows the summary statistics of the variables included in the regression models. Further, Levin-Lin-Chu (2002) panel data unit root test is carried out, and the results of the test are presented in Table 8. It is observed that the adjusted t statistic is statically significant at 1 percent for all the variables. This means that none of the variables included in the regression analysis suffers from the problem of unit-root, i.e., nonstationarity. The regression results show that the F-statistic is statistically significant for all of the three estimated equations (Table 9). This means that all the estimated equations are statistically significant. Furthermore, the value of adjusted the R2 is 
reasonably high for the equation on market structure and conduct. However, it is very low for the equation on performance, but this does not necessarily indicate that the estimated models are not acceptable. ${ }^{16}$ As regards the individual coefficients, the tstatistics are computed by using robust standard errors to control for the problem of heteroscedasticity further. In addition, presence of multicollinearity, if any, is examined in terms of the variance inflation factors (VIFs). It is found that the VIFs of all the independent variables are less than 10. Hence, following Marquardt (1970) and Mason et al. (1989), it can be said the estimated models do not suffer from the problem of severe multicollinearity. ${ }^{17}$

In the estimated equation on the determinants of market structure, it is observed that the coefficients of BSZit, SELLi,t-1, ROAit, D1 and D2 are statistically significant. While the coefficients of BSZit, SELLi,t-1 and ROAi,t-1 are positive, that of D1 and D2 are negative. This means that the banks with larger asset base, greater selling efforts and better financial performance in the past have larger share in the market. On the other hand, the negative coefficients of D1 and D2 suggest that the private domestic banks as well as the private foreign banks have lower market share vis-à-vis their public sector counterparts.

The direct relationships are well expected. The banks that are larger in size can reap the benefits of scale economies and hence can raise their market share. On the other hand, greater selling efforts help the banks in raising their market shares by creating image advantage and barriers to entry. A positive association between bank size and market share is consistent with experiences from other sectors. For example, in the context of Indian pharmaceutical industry, Mishra and Vikas (2010) found a positive impact of asset base of the firms on their market shares, though the impact of selling efforts was not statistically significant.

Similarly, the banks with better financial performance in the past have higher ability as well as greater willingness to grow and raise market share. On the other hand, it is generally perceived that better financial performance of the incumbents attract new entrants into the market. But, in many cases, better financial performance of the incumbents can also act as an entry barrier and may discourage the potential entrants from entering into the market. This is so particularly when the potential entrants do not have the capability to enhance their financial performance to the level of that of the incumbents. When it is so, better financial performance of the incumbents are likely to result in higher their market shares in future. The finding of lower market share of the private banks as compared to their public sector counter parts may largely be caused by their lesser penetration in the market banks as they are relatively new players in the sector and generally operate in the urban areas.

However, the coefficient of MSZi,t-1 is not statistically significant. This means that increase in demand for services of a bank does not necessarily result in its greater

\footnotetext{
${ }^{16}$ As pointed out by Goldberger (1991), the R2 has a very modest role in regression analysis. The classical linear regression model does not necessarily require that the value of the R2 should be high. Neither is a high value of the R2 evidence in favour of a model nor is a low value of the R2 evidence against it (Gujarati and Sangeetha, 2007).

${ }^{17}$ While Marquardt (1970) uses a VIF greater than 10 as a guideline for serious multicollinearity, according to Mason et al. (1989), a VIF of greater than 10 is as reason for concern.
} 
market share. Although it is generally expected that the banks with larger demand for services will have higher market shares, the finding of no statistically significant relationship between the two in the present paper is not surprising. A possible explanation for such finding may be the way the two variables are defined. While market size measures absolute presence of a bank in the sector, market share refers to its relative position. Therefore, when market size of other banks in the sector also increases, market share of an individual bank may not necessarily enhance, despite the rise in its own market size. However, any definite conclusion in this regard requires further exploration.

Hence, the structure of the market in Indian banking sector measured in terms of market shares of the banks depends on other structural aspects of the market like their asset base, conduct like selling efforts, and past financial performance. In other words, the SCP relationships in Indian banking sector is not unidirectional, as it was suggested by Bain (1956), where structure of the market influences performance via conduct. Instead, market structure is influenced by conducts of the banks and their financial performance, in addition to other structural aspects of the market. Since lagged selling efforts and lagged financial performance have significant impact on market share, the relationships are not instantaneous, and hence should be viewed in a dynamic context. Further, significant impact of bank size on market share suggests that different aspects of market structure are interdependent, and therefore, should not be considered in isolation of one another.

As regards the determinants of conducts, it is observed that all the estimated coefficients are statistically significant and positive. This implies that the banks, which have larger asset base and larger market share, and better financial performance in the past, make greater selling efforts. Further, the private banks, be it domestic or foreign, spend more for selling purposes as compared to the public sector banks. The banks with higher market share use the route of advertising and promotion of services to strengthen their position further in the market. These banks seem to aim at creating image advantage, strategic entry barriers, and marketing and distribution related complementary assets through their selling efforts to limit market competition in the long run. Similarly, the larger banks (i.e., the banks with larger asset base) spend more towards selling as they have greater ability to spend for this purpose, whereas better financial performance in the past enhances both ability and willingness of the banks to spend more towards selling. Greater selling efforts by the private banks may largely be due to their market driven business motives and approaches.

Thus, similarly to the market structure, the regression model on the determinants of conduct also suggests for multidirectional SCP relationships in Indian banking sector, which is contradictory to Bain's (1956) unidirectional SCP relationship where conducts are determined by structural aspects of the market. The regression results show that, in addition to structural aspects of the market like market share of the banks and their asset base, conducts of the banks are also determined by their financial performance. Since lagged market share and lagged financial performance have significant impact on banks' selling efforts, the relationships are not instantaneous, and hence should be viewed in a dynamic context. 
The results of the regression model on the determinants of financial performance show that the coefficients of all the variables except COSTit are statistically significant. While the coefficient of SHAREit, D1 and D2 are positive that of BSZit and SELLi,t-1 are negative. This means that the returns on assets are higher for the banks with larger market share. Furthermore, private banks, be it domestic or foreign, perform better financially as compared to the public sector banks. On the other hand, the banks which are larger in size or make greater selling efforts experience lower returns on assets. However, the coefficient of COSTit is not statistically significant which implies that costs efficiency does not have any significant impact on financial performance of the banks.

From the regression results it is, therefore, evident that financial performance of the banks is influenced by various structural aspects of the market structure, conducts of the banks and their past performance level. It is observed that higher shares of the banks in the market results in larger returns on assets either through greater efficiencies, or higher market power, or both. This is contradictory to the findings of Bhattacharya and Das (2003), Sathye and Sathye (2004), and Varma and Sainir (2010) that do not find evidence in support of the traditional SCP hypothesis that market concentration directly influences banks' financial performance in Indian context. However, such a positive relationship between market share and financial performance is consistent with the findings of Edward (1964), Phillips (1967), Brucker (1970), Vernon (1971), Gilbert (1984), Evanoff and Fortier (1988), Molyneux and Thornton (1992) and Katib (2004).

On the other hand, statistically significant but negative coefficients of bank size and selling intensity are surprising. This is so possibly because the size larger than the optimal level results in X-inefficiency, and hence lowers level of financial performance. Similarly, while it is generally expected that greater selling efforts would enhance financial performance of the banks, the finding of a negative coefficient of selling intensity is possibly due to failure on the part of the banks in creating image advantage and effective entry barriers through advertising. However, any definite conclusion in this regard requires further research. The regression results also suggest that the nature of ownership has a significant influence banks' finance performance, and in comparison to their public sector counterparts, private banks are better performers. Such better financial performance of the private banks may largely be caused by their greater capital base and better managerial efficiency.

Thus, like market structure and conduct, financial performance of the banks is also determined by a variety of variables relating to structure of the market, conducts of the banks, and other aspects of performance. This means that there are strong inter-linkages between market structure, business strategies and financial performance in Indian banking sector. Not only financial performance of the banks is influenced by their conducts and structure of the market; there are also strong feedback effects from performance to conduct and from conduct to structure. In Indian context, all these essentially make the SCP relationships multidirectional and dynamic in nature. In addition, financial performance of the banks is significantly influenced by the nature of ownership as well. 


\section{Summary Findings and Conclusions}

In the context of initiation of economic reforms in general, and changes in policies and regulations of the banking sector in particular, the present paper attempts to examine the structure-conduct-performance relationships in Indian banking sector. It is observed that there have been changes in the market structure of Indian banking sector, conducts of the banks and their performance during the post-reform period, though the changes may not necessarily be significant. Furthermore, strong inter-linkages exist amongst structure of the market, conduct of banks and their financial performance. While market share of a bank depends directly on its market size, asset base, selling efforts, and past financial performance, as well as its selling efforts vary directly with market share, asset base, and financial performance. On the other hand, returns on assets of a bank vary directly with its market share, but inversely with its asset base and selling efforts.

This means that the SCP relationships in Indian banking sector are not necessarily unidirectional. Not only the market share of a bank influences its selling efforts, the reverse causality also holds discarding the unidirectional relationships between market structure and business strategies of the banks. Similarly, while market share of a bank is influenced by its financial performance, the reverse causality also holds. In other words, there exist bidirectional relationships between market structure of the banks and their financial performance. The same can be said in respect of conduct-performance relationships as well.

The present paper also finds that nature of ownership of the banks plays a significant role in determining structure of the market in Indian banking sector, business strategies of the banks, and their financial performance. While market share of the private banks (both domestic and foreign) is lower as compared to that of the nationalised banks, they make greater selling efforts vis-à-vis their public sector counterparts. Further, the private banks have better financial performance when compared with that of the public sector banks.

The findings discussed above have some important policy implications. First, even though higher market share improves financial performance, it should also be ensured that the banks do not use their market power to charge monopoly prices for services. Rather, efforts should be made in encouraging the banks to emphasize on enhancing efficiency to improve their financial performance. However, the decision on whether the banks should be allowed to raise their market shares through selling efforts requires serious scrutiny as aggressive selling strategies may not only affect their financial performance adversely, but may also result in unfair and restrictive business practices.

Second, since larger asset base results in higher market share of the banks, their growth in terms of assets is a matter a serious concern. Moreover, given that it affects banks' financial performance adversely, possibly due to larger nonperforming assets and Xinefficiencies arising out of the larger size, efforts should be made in guiding the banks towards more efficient use of the assets and in managing X-inefficiencies. This is very important for enhancing competitiveness of the banks as well as their financial performance.

Third, the findings that the nature of ownership influences structure of the market, banks' conduct and their financial performance raises a few important policy concerns. 
What should be the policy approach to the private banks, especially to the domestic ones in respect of their business strategies? Should the RBI play a proactive regulatory role in this regard, particularly in respect of their unfair and restrictive business practices? Are customers and investors benefitted with the entry of private banks, and hence the changing dynamics of the sector? What are the macroeconomic implications of these changes? Addressing these issues is very important and requires further research to design appropriate policies and regulations.

\section{References:}

BAIN J. S. (1951). Relation of Profit Rate to Industry Concentration: American Manufacturing 1936-1940. Quarterly Journal of Economics. 65(3), pp. 293-325.

BAIN, J. S. (1959), Industrial Organization. New York: Wiley

BAKER, J. B., WOODWARD, P. A. (1998). Market Power and the Cross-industry Behaviour of Price around a Business Cycle Trough. Working Paper No. 221. Bureau of Economics. Federal Trade Commission.

BASANT, R., MORRIS, S. (2000). Competition Policy in India: Issues for a Globalising Economy. Project Report Submitted to the Ministry of Industry, Government of India, New Delhi.

BERGER, A. N., HANNAN, T. H. (1992). The Price Concentration Relationship in Banking: A Reply. Review of Economics and Statistics. 74(2), pp.376-389.

BERGER, A. N. (1995). The Profit-Structure Relationship in Banking: Tests of MarketPower and Efficient-Structure Hypotheses. Journal of Money, Credit and Banking. 27(2), pp. 404-431.

BHATTACHARYA, K., DAS, A. (2003). Dynamics of Market Structure and Competitiveness of the Banking Sector in India and its Impact on Output and Prices of Banking Services. Reserve Bank of India Occasional Papers. 24(3), pp. 124-159.

BRESNAHAN, T. F. (1989). Empirical Studies of Industries with Market Power. Handbook of Industrial Organization. Vol. 2, pp. 1011-57.

BRUCKER, E. (1970). A Microeconomic Approach to Banking Competition. Journal of Finance. 25(5), pp. 1133-1141.

CHO, Y.J. (1986). Inefficiencies from Financial Liberalization in the Absence of WellFunctioning Equity Markets. Journal of Money, Credit and Banking. 18(2), pp.191-199.

CHIAPPORI, P.A., PÉREZ-CASTRILLO, D., VERDIER, F. (1995). Spatial competition in the banking system, localization, cross-subsidies and the regulation of interest rates. European Economic Review. 39(5), pp. 889-919.

DELOMER, C. D., KLEIN, P. G., KAMERSCHEN, D. R., VOEKS, L. F. (2002). Structure Conduct and Performance: A Simultaneous Equations Approach. Applied Economics. 34(17), pp.13-20.

DEMSETZ, H. (1973). Industry Structure, Market Rivalry, and Public Policy. Journal of Law and Economics. 16(1), pp. 1-9. 
DEMSETZ, H. (1974). Two Systems of Belief about Monopoly. In H. Goldschmid, H. Michael Mann and J. Fred Weston, eds. Industrial Concentration: The New Learning. Boston: Little, Brown and Co., pp. 164-84.

EDWARD, F. R. (1964). Concentration in Banking and Its Effect on Business Loan Rates. Review of Economic and Statistics. 46(3), pp. 294-300.

EVANOFF, D., FORTIER, L. (1988). Re-evaluation of the Structure-ConductPerformance Paradigm in Banking. Journal of Financial Services Research. 1(3), pp. 277-294.

FRAME, W. S., D. R. KAMERSCHEN (1997). The Profit-Structure Relationship in Legally Protected Banking Markets Using Efficiency Measures. Review of Industrial Organization. 12, pp. 9-22.

GILBERT, A. (1984). Studies of Bank Market Structure and Competition: A Review and Evaluation. Journal of Money, Credit and Banking. 16, pp. 617-644.

GOLDBERGER, A. S. (1991). A course in Econometrics. Cambridge: Harvard University Press.

GRABEL, I. (1995). Assessing the Impact of Financial Liberalization on Stock Market Volatility in Selected Developing Countries. Journal of Development Studies. 31, pp. $903-917$.

GUJARATI, D. N., SANGEETHA. (2007). Basic Econometrics (4 $^{\text {th }}$ ed.). New Delhi: McGraw-Hill, Inc.

GUPTA, V. K. (1983). A Simultaneous Determination of Structure, Conduct and Performance in Canadian Manufacturing. Oxford Economic Papers. 35, pp. 281-301.

HANNAN, T. H., BERGER, A. N. (1989). Price rigidity and market structure: theory and evidence from the banking industry. Finance and Economics Discussion Series 59. Board of Governors of the Federal Reserve System (U.S.).

HANNAN, T. H. (1991).The Functional Relationship between Prices and Market Concentration: The Case of the Banking Industry. Finance and Economics Discussion Series 169. Board of Governors of the Federal Reserve System (U.S).

JOSHI, V., LITTLE, I.M.D. (1996). India's Economic Reforms 1991-2000. Oxford: Clarendon Press.

KATIB, N. M. (2004). Market Structure and Performance in the Malaysian Banking Industry: A Robust Estimation. $8^{\text {th }}$ Capital Market Conference. Indian Institute of Capital Market Paper.

KHAMBAMPATI, U. S. (1996). Industrial concentration and performance: a study of the structure, conduct, and performance of Indian industry. New Delhi: Oxford University Press.

KIRZNER, I. M. (1973). Competition and Entrepreneurship. Chicago: University of Chicago Press.

LEVIN, A., LIN, C. F., CHU, C. (2002). Unit Root Tests in Panel Data: Asymptotic and Finite-Sample Properties. Journal of Econometrics. 108, pp. 1-24. 
LLOYAD-WILlIAMS, D. M., MOLYNEUX, P., THORNTON, J. (1994). Market structure and performance in Spanish banking. Journal of Banking and Finance. 18(3), pp. 433-443.

MARQUARDT, D. W. (1970). Generalized Inverses, Ridge Regression, Biased Linear Estimation and Nonlinear Estimation. Technometrics. 12(3), pp. 591-612.

MARTIN, S. (1979a). Advertising, Concentration and Profitability: The Simultaneity Problem. Bell Journal of Economics. 10, pp. 639-47.

MARTIN, S. (1979b). Entry Barriers, Concentration and Profits. Southern Economic Journal, 46, pp. 471-88.

MASON, E. (1939). Price and Production Policies of Large-Scale Enterprise. American Economic Review. 29, pp. 61-74.

MASON, R. L., GUNST, R. F., HESS, J. L. (1989). Statistical Design and Analysis of Experiments: Applications to Engineering and Science. New York: John Wiley and Sons, Inc.

MILLER, R. L., VANHOOSE, D. D. (1993). Modern Money and Banking. (3rd ed.). New York: McGraw-Hill.

MISHRA, P., BEHERA, B. (2007). Instabilities in Market Concentration: An Empirical Investigation in Indian Manufacturing Sector. Journal of Indian School of Political Economy. 19(3), pp.119-149.

MISHRA, P. (2005). Mergers and Acquisitions in the Indian Corporate Sector in the Post- Liberalisation Era: An Analysis. Unpublished Doctoral Thesis. Vidyasagar University, West Bengal.

MISHRA, P. (2008). Concentration-Markup Relationship in Indian Manufacturing Sector. Economic and Political Weekly. 43(39), pp.76-81.

MISHRA, P., VIKAS. (2010). Structure, Conduct and Performance in Indian Pharmaceutical Industry: A Simultaneous Equations Investigation. Review of Development and Change, 15(1), pp. 69-99.

MOLYNEUX, P., THORNTON, J. (1992). Determinants of European Bank Profitability: A Note. Journal of Banking and Finance 16(6), pp.1173-1178.

MOLYNEUX, P., FORBES W. (1995). Market Structure and Performance in European Banking. Applied Economics. 27(2), pp.155-159.

MUELLER, D. C. (1990) (ed.). The Dynamics of Company Profits, An International Comparison. New York: Cambridge University Press.

MULLINEUX, A., SINCLAIR, P. (2000). Oligopolistic Banks: Theory and Policy Implications Unpublished .

NEUBERGER, D. (1997). Structure, Conduct and Performance in Banking Markets. Thuenen-Series of Applied Economic Theory 12. University of Rostock, Institute of Economics, Germany. 
NEUMARK, D., SHARPE, S. A. (1992). Market Structure and the Nature of Price Rigidity: Evidence from the Market for Consumer Deposits. The Quarterly Journal of Economics. 107(2), pp. 657-80.

OKEAHALAM, C.C. (1998). Concentration in the Banking Sector of the Common Monetary Area of Southern Africa. Paper was presented at the Development Issues in the New Economy Conference. University of Cape Town, South Africa. March 24-26 2002.

OSBORNE, D. K., WENDEL, J. (1983). Research in Structure, Conduct and Performance in Banking 1964-1979. Research paper 83-003. College of Business Administration, Oklahoma State University.

PRAGER, R., HANNAN. T. H. (1998). Do Substantial Horizontal Mergers Generate Significant Price Effects? Evidence from the Banking Industry. Journal of Industrial Economics. 46(4), pp. 433-452.

PHILLIPS, A. (1967). Evidence of Concentration in Banking Markets and Interest Rates. Federal Reserve Bulletin. 53(6), pp. 916-926.

PODENDA, R. J. (1986). Structure and performance: Some evidence from California banking, Economic Review. Federal Reserve Bank of Sanfrancisco (winter), 5-17.

PUSHPANGADAN, K., SHANTA, N. (2008). Competition and Profitability in Indian Manufacturing Sector. Indian Economic Review. 43(1), pp. 103-123.

RAM MOHAN, T.T. (2001). Long run performance of public and private sector bank stocks Economic And Political Weekly. 36(52), pp. 4865-4871.

RAMASWAMY, K. V. (2006). State of Competition in Indian Manufacturing Industry. In Mehta, P. S. (Ed). A Functional Competition Policy for India. New Delhi: Academic Foundation.

RHOADES, S. A. (1985). Market Share as a Source of Market Power: Implications and Some Evidence. Journal of Economics and Business. 37(4), pp. 343-365.

SCHERER, F.M., ROSS, D. (1990). Industrial Market Structure and Economic Performance. Boston: Houghton Mifflin.

SCHMALENSEE, R. (1989). Inter-industry Studies of Structure and Performance. In R. Schmalensee and R. Willig (ed.) Handbook of Industrial Organization. Vol. 2, New York: North Holland. pp. 952-1009.

SHACKLE, G. L. S. (1971). Economics for Pleasure. Cambridge: Cambridge University Press.

SHAFFER, S. (1989). Competition in the U.S. banking industry. Economics Letters. 29(4), pp. 321-323.

SINGH, A. (1993). Stock Markets, Financial Liberalization, and Economic Development. Economic Journal. 107(442), pp. 771-782.

SMIRLOCK, M. (1985). Evidence on the (non) Relationship between Concentration and Profitability in Banking. Journal of Money, Credit and Banking. 17(1), pp.69-83. 
STRICKLAND, A. D., WEISS, L. W. (1976). Advertising, Concentration and PriceCost Margins Journal of Political Economy. 84(5), pp. 1109-1121.

SWANK, J. (1996). Theories of the Banking Firm: A Review of the Literature. Bulletin of Economic Research. 48(3), pp.173-207.

THAKOR, A.V. (1995). Financial Intermediation and the Market for Credit. edited by Jarrow, Handbooks in Operations Research and Management Science. Elsevier Science. Vol. 9, pp. 1073-1103.

VERNON, J. R. (1971). Separation of ownership and control and profits rates, the evidence from banking: Comment. Journal of Financial and Quantitative Analysis. 6(1), pp. 615-625.

VERMA, S., SAINIR, R. (2010). Structure Conduct and Performance of commercial bank in India. Prajnan. 39(2), pp. 39-45.

VICKERS, J. (1995). Concepts of Competition. Oxford Economic Papers. 47(1), pp. 123.

WEISS, L. (1974). The Concentration-Profits Relationship and Antitrust. In Audretsch, D., Yamawaki, H., (eds), Industrial Concentration: The New Learning Boston: Little Brown and Company. 


\section{Appendix - I}

Table 1: Composition of Indian Banking Sector

\begin{tabular}{|l|r|r|r|r|r|}
\hline \multirow{2}{*}{ Year } & \multicolumn{5}{|c|}{ Number of Banks } \\
\cline { 2 - 4 } & \multirow{2}{*}{ Nationalized } & \multicolumn{2}{|c|}{ Private } & \multirow{2}{*}{ Others } & \multirow{2}{*}{ Total } \\
\cline { 3 - 4 } & & Domestic & \multicolumn{1}{|c|}{ Foreign } & & \\
\hline $2000-01$ & $29(22.8)$ & $19(15.0)$ & $34(26.8)$ & $45(35.4)$ & $127(100)$ \\
\hline $2001-02$ & $29(23.6)$ & $23(18.7)$ & $35(28.4)$ & $36(29.3)$ & $123(100)$ \\
\hline $2002-03$ & $29(22.5)$ & $24(18.6)$ & $31(24.0)$ & $45(34.9)$ & $129(100)$ \\
\hline $2003-04$ & $29(21.0)$ & $22(15.9)$ & $31(22.5)$ & $56(40.6)$ & $138(100)$ \\
\hline $2004-05$ & $29(20.9)$ & $21(15.1)$ & $31(22.3)$ & $58(41.7)$ & $139(100)$ \\
\hline $2005-06$ & $29(22.7)$ & $21(16.4)$ & $26(20.3)$ & $52(40.6)$ & $128(100)$ \\
\hline $2006-07$ & $28(21.7)$ & $26(20.2)$ & $28(21.7)$ & $47(36.4)$ & $129(100)$ \\
\hline $2007-08$ & $28(23.9)$ & $23(19.7)$ & $26(22.2)$ & $40(34.2)$ & $117(100)$ \\
\hline $2008-09$ & $28(25.2)$ & $22(19.8)$ & $24(21.6)$ & $37(33.3)$ & $111(100)$ \\
\hline $2009-10$ & $28(27.5)$ & $16(15.7)$ & $22(21.6)$ & $36(35.3)$ & $102(100)$ \\
\hline
\end{tabular}

Note: $\quad$ Figures in parentheses indicate percentage share to total

Source: Prowess (CMIE)

Table 2: Basic Conditions of Indian Banking Sector

\begin{tabular}{|c|r|r|r|r|}
\hline \multirow{2}{*}{ Year } & \multicolumn{2}{|c|}{ Market Size } & \multicolumn{2}{c|}{ Bank Size } \\
\cline { 2 - 5 } & Average & C.V. & Average & C.V. \\
\hline $2000-01$ & 5.20 & 0.42 & 7.33 & 0.30 \\
\hline $2001-02$ & 5.36 & 0.39 & 7.53 & 0.29 \\
\hline $2002-03$ & 5.24 & 0.44 & 7.36 & 0.33 \\
\hline $2003-04$ & 5.19 & 0.45 & 7.41 & 0.32 \\
\hline $2004-05$ & 5.01 & 0.51 & 7.37 & 0.34 \\
\hline $2005-06$ & 5.19 & 0.49 & 7.68 & 0.32 \\
\hline $2006-07$ & 5.18 & 0.52 & 7.65 & 0.35 \\
\hline $2007-08$ & 5.69 & 0.46 & 8.14 & 0.33 \\
\hline $2008-09$ & 6.15 & 0.41 & 8.56 & 0.30 \\
\hline $2009-10$ & 6.57 & 0.37 & 8.90 & 0.28 \\
\hline
\end{tabular}

Note: Market Size - Natural logarithm of sales; Bank Size - Natural logarithm of assets; Net Worth - Natural Logarithm of Net Worth; $\quad$ C.V. - Coefficient of Variation Source: Prowess (CMIE) 
Table 3: Structure of Indian Banking Sector

\begin{tabular}{|c|c|c|c|c|c|c|}
\hline \multirow[b]{2}{*}{ year } & \multirow{2}{*}{$\begin{array}{l}\text { No. of } \\
\text { bank }\end{array}$} & \multicolumn{2}{|c|}{ Market Share } & \multirow{2}{*}{$\begin{array}{c}\text { 3-firm } \\
\text { Concentration } \\
\text { Ratio } \\
\end{array}$} & \multirow[b]{2}{*}{ HHI } & \multirow{2}{*}{$\begin{array}{c}\text { Entropy } \\
\text { Index }\end{array}$} \\
\hline & & Average & C.V. & & & \\
\hline $2000-01$ & 127 & 0.01 & 2.65 & 0.32 & 0.06 & 3.58 \\
\hline 2001-02 & 123 & 0.01 & 2.63 & 0.31 & 0.06 & 3.56 \\
\hline 2002-03 & 129 & 0.01 & 2.67 & 0.31 & 0.06 & 3.57 \\
\hline 2003-04 & 138 & 0.01 & 2.75 & 0.32 & 0.06 & 3.58 \\
\hline 2004-05 & 139 & 0.01 & 2.77 & 0.32 & 0.06 & 3.54 \\
\hline $2005-06$ & 128 & 0.01 & 2.66 & 0.32 & 0.06 & 3.52 \\
\hline 2006-07 & 129 & 0.01 & 2.59 & 0.32 & 0.06 & 3.51 \\
\hline 2007-08 & 117 & 0.01 & 2.26 & 0.31 & 0.05 & 3.55 \\
\hline 2008-09 & 111 & 0.01 & 2.21 & 0.31 & 0.05 & 3.54 \\
\hline 2009-10 & 102 & 0.01 & 2.06 & 0.29 & 0.05 & 3.54 \\
\hline
\end{tabular}

Note: C.V. - Coefficient of Variation

Source: Prowess (CMIE)

Table 4: Strategies of Indian Banks, 2000-01 to 2009-10

\begin{tabular}{|c|r|r|}
\hline \multirow{2}{*}{ year } & \multicolumn{2}{|c|}{ Selling Intensity } \\
\cline { 2 - 3 } & Average & C.V. \\
\hline $2000-01$ & 0.23 & 6.11 \\
\hline $2001-02$ & 0.28 & 1.92 \\
\hline $2002-03$ & 0.30 & 4.52 \\
\hline $2003-04$ & 0.34 & 2.16 \\
\hline $2004-05$ & 0.48 & 3.18 \\
\hline $2005-06$ & 0.65 & 2.69 \\
\hline $2006-07$ & 0.79 & 2.38 \\
\hline $2007-08$ & 0.75 & 2.09 \\
\hline $2008-09$ & 0.78 & 3.06 \\
\hline $2009-10$ & 0.48 & 3.59 \\
\hline
\end{tabular}

Note: C.V. - Coefficient of Variation

Source: Prowess (CMIE) 
Table 5: Performance of Indian Banks, 2000-01 to 2009-10

\begin{tabular}{|c|r|r|r|r|r|r|}
\hline \multirow{2}{*}{ Year } & \multicolumn{1}{|c|}{ PBIT/Income } & \multicolumn{2}{|c|}{ PBIT/Asset } & \multicolumn{2}{|c|}{ ROCE } \\
\cline { 2 - 7 } & Average & C.V. & Average & C.V. & Average & C.V. \\
\hline $2000-01$ & 65.67 & 0.32 & 7.43 & 0.36 & 7.21 & 2.98 \\
\hline $2001-02$ & 67.95 & 0.30 & 7.35 & 0.44 & 2.47 & 11.1 \\
\hline $2002-03$ & 67.85 & 0.37 & 7.31 & 0.65 & 8.16 & 1.75 \\
\hline $2003-04$ & 66.43 & 0.36 & 7.09 & 0.64 & 7.75 & 1.79 \\
\hline $2004-05$ & 65.25 & 0.66 & 6.24 & 0.54 & 5.38 & 10.0 \\
\hline $2005-06$ & 55.37 & 0.91 & 4.70 & 0.46 & 2.80 & 1.25 \\
\hline $2006-07$ & 62.06 & 0.22 & 5.80 & 0.47 & 5.28 & 1.48 \\
\hline $2007-08$ & 65.10 & 0.17 & 5.59 & 0.21 & 5.92 & 1.21 \\
\hline $2008-09$ & 70.30 & 0.19 & 6.48 & 0.23 & 3.48 & 13.5 \\
\hline $2009-10$ & 72.30 & 0.20 & 6.96 & 0.91 & 7.32 & 1.09 \\
\hline
\end{tabular}

Note: C.V. - Coefficient of Variation; PBIT - Profit before Interests and Taxes; ROCE

- Return on Capital Employed

Source: Prowess (CMIE)

Table 6: Cost Efficiency of Indian Banks, 2000-01 to 2009-10

\begin{tabular}{|l|r|r|r|r|r|r|}
\hline \multirow{2}{*}{ year } & \multicolumn{2}{|c|}{$\begin{array}{c}\text { Operating } \\
\text { Expenditure/Income }\end{array}$} & \multicolumn{2}{c|}{$\begin{array}{c}\text { Total } \\
\text { Expenditure/Income }\end{array}$} & \multicolumn{2}{c|}{ Current Ratio } \\
\cline { 2 - 7 } & Average & C.V. & Average & \multicolumn{1}{c|}{ C.V. } & Average & \multicolumn{1}{c|}{ C.V. } \\
\hline $2000-01$ & 71.56 & 0.25 & 74.66 & 0.99 & 0.71 & 0.23 \\
\hline $2001-02$ & 71.86 & 0.22 & 74.87 & 1.42 & 0.74 & 0.21 \\
\hline $2002-03$ & 67.53 & 0.26 & 70.30 & 1.51 & 0.71 & 0.27 \\
\hline $2003-04$ & 62.35 & 0.23 & 65.35 & 1.50 & 0.69 & 0.20 \\
\hline $2004-05$ & 58.55 & 0.31 & 61.84 & 1.92 & 0.66 & 0.29 \\
\hline $2005-06$ & 59.06 & 1.87 & 63.39 & 2.71 & 0.94 & 1.78 \\
\hline $2006-07$ & 60.83 & 7.07 & 64.86 & 2.77 & 1.26 & 7.07 \\
\hline $2007-08$ & 61.11 & 0.23 & 64.87 & 1.78 & 0.66 & 0.21 \\
\hline $2008-09$ & 61.21 & 0.26 & 64.86 & 1.40 & 0.66 & 0.24 \\
\hline $2009-10$ & 61.20 & 0.26 & 64.86 & 2.50 & 0.65 & 0.24 \\
\hline
\end{tabular}

Note: C.V. - Coefficient of Variation

Source: Prowess (CMIE) 
Table 7: Summary Statistics of the Variables

\begin{tabular}{|l|r|r|r|r|}
\hline \multicolumn{1}{|c|}{ Variable } & \multicolumn{1}{c|}{ Mean } & \multicolumn{1}{c|}{ Std. dev. } & \multicolumn{1}{c|}{ Min } & \multicolumn{1}{c|}{ Max } \\
\hline SHARE $_{\text {it }}$ & -5.3363 & 1.9142 & -10.6748 & -1.5055 \\
\hline BSZ $_{\text {it }}$ & 2.0102 & 0.3932 & 0.5108 & 2.6031 \\
\hline SELL $_{\text {it }}$ & 0.8540 & 2.6406 & -5.7038 & 7.3891 \\
\hline PROA $_{i t}$ & -2.8152 & 0.2706 & -4.6332 & -1.8769 \\
\hline NW $_{\text {it }}$ & 1.8807 & 0.2695 & 0.7099 & 2.3708 \\
\hline TOC $_{\text {it }}$ & -2.1246 & 1.0614 & -7.0062 & 0.7651 \\
\hline SHARE $_{\mathrm{i}, \mathrm{t}-1}$ & -5.3816 & 1.8857 & -10.6748 & -1.5055 \\
\hline MSZ $_{\mathrm{i}, \mathrm{t}-1}$ & 1.7522 & 0.3934 & 0.1824 & 2.3784 \\
\hline SELL $_{\mathrm{i}, \mathrm{t}-1}$ & 0.6062 & 2.5728 & -5.7038 & 7.3891 \\
\hline ROA $_{\mathrm{i}, \mathrm{t}-1}$ & -2.7967 & 0.2927 & -4.6332 & -1.8769 \\
\hline PROF $_{\mathrm{i}, \mathrm{t}-1}$ & -0.4566 & 0.2050 & -1.7931 & -0.1046 \\
\hline D1 & 0.2712 & 0.4451 & 0.0000 & 1.0000 \\
\hline D2 & 0.3220 & 0.4678 & 0.0000 & 1.0000 \\
\hline
\end{tabular}

Source: Prowess (CMIE)

Table 8: Results of Panel Unit-Root Test

\begin{tabular}{|l|c|}
\hline \multicolumn{1}{|c|}{ Variables } & Adjusted t-Statistic \\
\hline SHARE $_{\text {it }}$ & $-48.13^{*}$ \\
\hline BSZ $_{\text {it }}$ & $-23.93^{*}$ \\
\hline SELL $_{\text {it }}$ & $-140.00^{*}$ \\
\hline PROA $_{i t}$ & $-38.39^{*}$ \\
\hline TOC $_{i t}$ & $-31.04^{*}$ \\
\hline NW $_{\text {it }}$ & $-11.78^{*}$ \\
\hline SHARE $_{\mathrm{i},-1}$ & $-94.63^{*}$ \\
\hline MSZ $_{\mathrm{i}, \mathrm{t}-1}$ & $-45.21^{*}$ \\
\hline SELL $_{\mathrm{i}, \mathrm{t}-1}$ & $-55.05^{*}$ \\
\hline ROA $_{\mathrm{i}, \mathrm{t}-1}$ & $-27.19^{*}$ \\
\hline PROF $_{\mathrm{i}, \mathrm{t}-1}$ & $-47.32^{*}$ \\
\hline
\end{tabular}

Note: *Statistically significant at 1 percent 
Table 9: Regression Results

\begin{tabular}{|l|r|r|r|}
\hline \multicolumn{4}{|c|}{ Determinants of Structure } \\
\hline \multicolumn{1}{|c|}{ Variable } & Coefficient & t-Statistic & VIF \\
\hline Intercept & -8.7054 & $-10.98^{*}$ & \\
\hline BSZ $_{\text {it }}$ & 3.3337 & $9.73^{*}$ & 1.54 \\
\hline MSZ $_{\text {it-1 }}$ & 0.3566 & 1.06 & 4.16 \\
\hline SELL $_{\text {it- }}$ & 0.2214 & $5.88^{*}$ & 3.35 \\
\hline ROA $_{\text {it-1 }}$ & 1.2686 & $5.84^{*}$ & 1.02 \\
\hline $\mathrm{D}_{1}$ & -0.7708 & $-5.66^{*}$ & 1.35 \\
\hline $\mathrm{D}_{2}$ & -1.0130 & $-6.41^{*}$ & 1.93 \\
\hline F-Stat & $207.56^{*}$ & & \\
\hline Adj-R & 0.71 & & \\
\hline No. of Observation & 406 & & \\
\hline
\end{tabular}

\begin{tabular}{|l|r|r|r|}
\hline \multicolumn{4}{|c|}{ Determinants of Conduct } \\
\hline \multicolumn{1}{|c|}{ Variable } & Coefficient & t-Statistic & VIF \\
\hline Intercept & -3.7508 & $-2.17^{* *}$ & \\
\hline SHARE $_{\mathrm{i}, \mathrm{t}-1}$ & 0.6803 & $5.90^{*}$ & 2.30 \\
\hline $\mathrm{BSZ}_{\mathrm{it}}$ & 4.8390 & $8.22^{*}$ & 1.52 \\
\hline $\mathrm{ROA}_{\mathrm{i}, \mathrm{t}-1}$ & 0.7867 & $2.06^{* *}$ & 1.04 \\
\hline $\mathrm{D}_{1}$ & 1.4352 & $6.54^{*}$ & 1.40 \\
\hline $\mathrm{D}_{2}$ & 1.0649 & $3.32^{*}$ & 2.29 \\
\hline & & & \\
\hline F-Stat & $144.53^{*}$ & & \\
\hline Adj-R & 0.62 & & \\
\hline No. of Observation & 404 & & \\
\hline
\end{tabular}

\begin{tabular}{|l|r|r|r|}
\hline \multicolumn{4}{|c|}{ Determinants of Performance } \\
\hline \multicolumn{1}{|c|}{ Variable } & Coefficient & t-Statistic & VIF \\
\hline Intercept & -1.7057 & $-4.37^{*}$ & \\
\hline SHARE $_{\text {it }}$ & 0.1157 & $3.86^{*}$ & 8.54 \\
\hline BSZ $_{\text {it }}$ & -0.2973 & $-2.26^{* *}$ & 1.44 \\
\hline SELL $_{\text {it- } 1}$ & -0.0404 & $-2.93^{*}$ & 5.54 \\
\hline COST $_{\text {it }}$ & -0.0265 & -0.79 & 1.16 \\
\hline $\mathrm{D}_{1}$ & 0.1376 & $4.04^{*}$ & 2.00 \\
\hline $\mathrm{D}_{2}$ & 0.0956 & $1.78^{* * *}$ & 2.98 \\
\hline F-Stat & $4.32^{*}$ & & \\
\hline Adj-R & 0.12 & & \\
\hline No. of Observation & 397 & & \\
\hline
\end{tabular}

Note: * 1\% significance level; $* * 5 \%$ significance level; $* * * 10 \%$ significance level 


\section{Appendix II}

\section{Measurement of the variables}

As mentioned earlier, in the present paper, the system of equations are estimated by using pooled data collected from the Prowess data base of the Centre for Monitoring Indian Economy (CMIE). In order to control for measurement errors, if any, three years moving average is taken for each component of the variable used.

Market Share: Market share of bank $i$ in year $t\left(\mathrm{SHARE}_{\mathrm{it}}\right)$ is measured as the ratio of its income (INC) to total income of all the banks in the sector, i.e.,

$$
\text { SHARE }_{i t}=\frac{1}{3}\left[\frac{I N C_{i t}}{\sum_{i=1}^{n} I N C_{i t}}+\frac{I N C_{i, t-1}}{\sum_{i=1}^{n} I N C_{i, t-1}}+\frac{I N C_{i, t-2}}{\sum_{i=1}^{n} I N C_{i, t-2}}\right]
$$

Market Size: Market size of bank $i$ in year $t\left(\mathrm{MSZ}_{\mathrm{it}}\right)$ is measured as the natural logarithm of its income (INC), i.e.,

$$
M S Z_{i t}=\frac{1}{3}\left[\ln \left(I N C_{i t}\right)+\ln \left(I N C_{i, t-1}\right)+\ln \left(I N C_{i, t-2}\right)\right]
$$

Bank Size: Size of bank $i$ in year $t$ (BSZ) is measured as natural logarithm of its total assets (ASSET), i.e.,

$$
B S Z_{i t}=\frac{1}{3}\left[\ln \left(A S S E T_{i t}\right)+\ln \left(A S S E T_{i, t-1}\right)+\ln \left(A S S E T_{i, t-2}\right)\right]
$$

Selling Intensity: Selling intensity of bank $i$ in year $t\left(\mathrm{SELL}_{\mathrm{it}}\right)$ is measured as the ratio of its total expenditure for selling purpose (advertisement, marketing and distribution) (SE) to its income (INC), i.e.,

$$
S E L L_{i t}=\frac{1}{3}\left[\frac{S E_{i t}}{I N C_{i t}}+\frac{S E_{i, t-1}}{I N C_{i, t-1}}+\frac{S E_{i, t-2}}{I N C_{i, t-2}}\right]
$$

Cost Intensity: Cost intensity of bank $i$ in year $t\left(\mathrm{COST}_{\mathrm{it}}\right)$ is measured by the ratio of its total expenditure (TE) to total income (INC), i.e.,

$\operatorname{COST}_{i t}=\frac{1}{3}\left[\frac{T E_{i t}}{I N C_{i t}}+\frac{T E_{i, t-1}}{I N C_{i, t-1}}+\frac{T E_{i, t-2}}{I N C_{i, t-2}}\right]$

Returns on Assets: Returns on assets of bank $i$ in year $t\left(\mathrm{PROF}_{\mathrm{it}}\right)$ is measured as the ratio of profit before interests and taxes (PBIT) of the bank to its total assets (ASSET), i.e.,

$$
R O A_{i t}=\frac{1}{3}\left[\frac{P B I T_{i t}}{A S S E T_{i t}}+\frac{P B I T_{i, t-1}}{A S S E T_{i, t-1}}+\frac{P B I T_{i, t-2}}{A S S E T_{i, t-2}}\right]
$$

Net Worth: In the present paper, data on net worth (NW) is sourced from the Prowess database of CMIE. The database measures net worth of a firm in terms of what it owes the equity share holders. This consists of the money put into the company by the equity 
share holders in the form of equity capital and the profits generated and retained as reserves by the firm. Like other variables, three years moving average is taken for net worth as well, i.e.,

$N W_{i t}=\frac{1}{3}\left[\ln \left(N W_{i t}\right)+\ln \left(N W_{i, t-1}\right)+\ln \left(N W_{i, t-2}\right)\right]$ 